\title{
Pengembangan model latihan imagery untuk peningkatan ketepatan floating service atlet voli pantai
}

\author{
Johan Irmansyah *, Muhammad Ridwan Lubis, Andi Gilang Permadi, Nune Wire Panji Sakti \\ Program Studi Pendidikan Olahraga dan Kesehatan, Universitas Pendidikan Mandalika. \\ Jalan Pemuda No. 59A Mataram, Nusa Tenggara Barat, Indonesia. \\ * Corresponding Author. Email: joevoley@gmail.com
}

Received: 3 November 2019; Revised: 12 December 2019; Accepted: 20 December 2019

\begin{abstract}
Abstrak
Penelitian ini bertujuan untuk: (1) menghasilkan sebuah model latihan imagery untuk peningkatan kete-patan floating service pada atlet voli pantai di NTB, dan (2) mengetahui keefektifan model latihan imagery untuk peningkatan ketepatan floating service atlet voli pantai di NTB. Penelitian ini menggunakan metode penelitian dan pengembangan atau yang sering disebut research and development yang mana digunakan untuk menghasilkan sebuah produk yang diinginkan. Hasil penelitian ini, yaitu studi pendahuluan, uji skala kecil dan skala besar yang telah dilakukan dengan percobaaan floating service dan instrument yang telah teruji validitas dan reliabilitasnya, dinyatakan bahwa penilaian para ahli terhadap model latihan imagery untuk meningkatkan ketepatan floating service dikatakan 'layak' untuk diterapkan di lapangan. Untuk uji efektifitas produk akhir, dari hasil analisis uji t menggunakan Paired Sample Test, menunjukkan bahwa peningkatan pretest-posttest ketepatan floating service dengan nilai t sebesar 8.104 dan signifikansi $0.000<$ 0.05, maka dapat disimpulkan bahwa peningkatan floating service sebelum dan sesudah diberikan latihan imagery mendapatkan peningkatan yang signifikan atau ada pengaruh yang signifikan dari latihan imagery untuk peningkatan ketepatan floating service.
\end{abstract}

Kata Kunci: pengembangan model, latihan imagery, floating service.

\section{Development of exercise model imagery to impove the accuracy of floating service in beach volleyball athlete}

\begin{abstract}
This study aims to: (1) produce an exercise model of imagery to improve the accuracy of floating service in NTB beach volleyball athletes, and (2) determine the effectiveness an exercise model of imagery to improve the accuracy of floating service in NTB beach volleyball athletes. This research uses research and development methods or often called research and development which is used to produce a desired product. The results of this study, namely a preliminary study, small scale and large scale tests that have been carried out with a trial of floating services and instruments that have been tested for validity and reliability, stated that experts' assessment of imagery training models to improve the accuracy of floating services is said to be 'feasible' in the field. To test the effectiveness of the final product, the results of the t-test analysis using Paired Sample Test, showed that the increase in pretest-posttest floating service accuracy with a $t$ value of 8,104 and significance of 0,000 $<0.05$, it can be concluded that the increase in floating service before and after imagery training was given get a significant in-crease or there is a significant effect of imagery training on improving the accuracy of floating services.
\end{abstract}

Keywords: model development, imagery training, floating service.

How to Cite: Irmansyah, J., Lubis, M., Permadi, A., \& Sakti, N. (2019). Model latihan imagery untuk peningkatan ketepatan floating service atlet voli pantai. Jurnal Keolahragaan, $7(2)$, 162-173. doi:https://doi.org/10.21831/jk.v7i2.21837

dc

https://doi.org/10.21831/jk.v7i2.21837

\section{PENDAHULUAN}

Voli pantai merupakan variasi dari permainan bola voli yang dimainkan di atas pasir (Irmansyah, 2017; Irmansyah et al., 2018;
Priyanto et al., 2014). Pada dasarnya, sebagian besar peraturan dan teknik-teknik yang terdapat pada permainan bola voli pantai sama dengan permainan bola voli indoor. Menurut Palao et al. (2009, p. 285) dikemukakan bahwa keterampilan 
teknik permainan bola voli dapat dibagi dalam enam bagian: (1) sikap penjagaan dan cara pergerakan, (2) passing dan umpan (passing bawah, passing atas dan umpan), (3) servis (servis bawah, servis dari samping dan servis atas), (4) spike/smash, (5) bendungan (blocking), (6) penerimaan bola (receive). Teknik dasar yang menjadi fokus atau objek dalam penelitian ini adalah servis atas, yang dimana salah satu teknik dalam melakukan servis atas adalah dengan floating service (servis mengambang).

Floating service merupakan salah satu servis yang dikembangkan dikarenakan kesukaran lawan dalam menerima servis terletak pada sifat jalannya bola yang mengapung/mengambang, serta jalannya bola pada lintasan lurus, kecepatan yang tidak teratur, bola sering melayang ke kiri dan ke kanan. MacKenzie et al. (2012, p. 581) menyatakan bahwa floating service adalah jenis servis dimana jalannya bola dari hasil pukulan servis itu tidak mengandung putaran, dengan kata lain bola berjalan mengapung atau mengambang. Dengan demikian tingkat kesulitan dalam melakukan floating service lebih tinggi jika dibandingkan dengan servis normal. Selain membutuhkan teknik servis yang baik, dibutuhkan juga mental dan kepercayaan diri seorang atlet. Oleh karena itu dibutuhkan latihan yang terfokus pada aspek psikologis (mental) atlet dalam melakukan floating service. Secara teoritis, Sukadiyanto dan Muluk (2011, p. 44) mengemukakan bahwa, ada empat aspek latihan yang perlu diperhatikan dan dilatih secara seksama, yaitu latihan fisik, latihan teknik, latihan taktik, dan latihan mental (psikologis). Ini menunjukkan bahwa latihan mental (psikologis) merupakan bagian yang tak terpisahkan dari aspek latihan, sehingga harus diprioritaskan sebagaimana aspek-aspek latihan yang lain.

Dalam penelitian ini, akan difokuskan pada aspek psikologis dari atlet, karena aspek ini masih kurang menjadi perhatian oleh beberapa pelatih dan pembina olahraga. Seringkali terdengar bahwa kekalahan dari atlet karena faktor psikologis mereka, tetapi jarang sekali kita mendengar komentar pelatih bahwa seorang atlet dapat memenangkan pertandingan disebabkan oleh aspek psikologis, seakan aspek psikologis merupakan sebuah kesalahan dan menjadi alasan non teknis sebagai pertahanan diri dari kekalahan yang dialami seorang atlet (Firmansyah, 2011).

Irmansyah et al. (2018, p. 104) menunjukkan bahwa dari hasil studi pendahuluan di lapangan, terdapat permasalahan mendasar pada program latihan yang disusun pelatih voli pantai yang harus segera mendapatkan solusi berupa pengembangan model latihan imagery untuk peningkatan ketepatan floating service, yaitu: (1) Program latihan dasar yang khusus untuk melakukan floating sevice masih belum maksimal dilakukan oleh para atlet karena metode latihan yang konstan dan alokasi waktu yang kurang efisien dalam penerapan latihan; (2) Program latihan yang disusun oleh pelatih masih didominasi pada aspek latihan fisik, teknik, dan taktik daripada mengeksplorasi latihan fundamental dari floating service yang merupakan serangan utama dalam permainan bola voli; (3) Metode latihan imagery yang difokuskan untuk meningkatkan aspek psikologis atlet masih belum diterapkan oleh para pelatih; dan (4) Proses evaluasi yang dilakukan pelatih masih mendeskripsikan secara umum kemampuan para atlet tanpa menelaah latihan-latihan fundamental yang bisa meningkatkan motivasi atlet dalam melakukan latihan maupun pertandingan.

Hubungannya dengan penelitian ini adalah, peneliti ingin memberikan sebuah metode latihan psikologis untuk atlet voli pantai agar mampu meningkatkan ketepatan floating service, model latihannya berupa pengembangan latihan imagery. Mizuguchi et al. (2012, p. 103) mengemukakan bahwa adanya hubungan erat antara imagery dan penampilan atlet dalam olahraga, sehingga untuk dapat berprestasi harus ada kepercayaan diri atlet bahwa dirinya sanggup dan mampu untuk mencapai prestasi yang diinginkan. Hal ini juga ditekankan oleh Filgueiras (2017, p. 72) bahwa latihan imagery membantu atlet untuk menjadi lebih percaya diri, meningkatkan kinerja yang berhubungan dengan keterampilan olahraga, dan membangun aktivitas olahraga yang lebih baik. Dalam perspektif imagery ada suatu perbedaan yang dirasakan seseorang antara imagery secara tidak nyata (internal imagery) dan imagery secara nyata (eksternal imagery) (Jose \& Joseph, 2018, p. 191). Eksternal imagery adalah ketika seseorang dapat melihat dirinya sendiri melalui media di luar dirinya seperti melihat dari video/alat rekam, sedangkan internal imagery adalah ketika seseorang berimajinasi seakan nyata melakukan suatu keterampilan. Jadi latihan imagery akan bekerja efektif ketika kinestetik imagery bersamaan dengan perspektif imagery (internal dan eksternal).

Berdasarkan hal tersebut, maka pengembangan model latihan imagery ini bertujuan untuk menghasilkan kelayakan sebuah model latihan imagery dan pengujian efektivitas model latihan imagery untuk peningkatan ketepatan floating service pada atlet voli pantai di NTB. 
Jurnal Keolahragaan 7 (2), 2019 - 164

Johan Irmansyah, Muhammad Ridwan Lubis, Andi Gilang Permadi, Nune Wire Panji Sakti

\section{METODE}

Penelitian ini menggunakan metode penelitian dan pengembangan atau yang sering disebut research and development yang mana digunakan untuk menghasilkan sebuah produk yang diinginkan (Fani \& Sukoco, 2019). Metode research and development merupakan metode penelitian yang digunakan untuk menghasilkan produk tertentu yang didahului oleh penelitian yang bersifat analisis kebutuhan dan diakhiri dengan pengujian keefektifan produk agar dapat berfungsi di masyarakat luas (Sugiyono, 2010, p. 297). Sejalan dengan pendapat teori research and development maka penelitian ini dilakukan untuk menghasilkan sebuah model latihan imagery untuk meningkatkan ketepatan floating service.

Gall et al. (2003, p. 152) menjelaskan bahwa model penelitian dan pengembangan memiliki sepuluh langkah pelaksanaan penelitian sebagai berikut: (1) studi pendahuluan dan pengumpulan data (kajian pustaka, pengamatan lapangan, membuat kerangka kerja penelitian), (2) perencanaan (tujuan penelitian, dana, waktu, prosedur penelitian, berbagai bentuk partisipasi, (3) mengembangkan produk awal (perencanaan draft awal produk), (4) ujicoba awal (mencoba draft produk ke wilayah dan subjek yang terbatas), (5) revisi untuk menyusun produk utama, (6) uji coba lapangan utama (uji coba ke wilayah dan subjek yang lebih luas), (7) revisi untuk menyusun produk operasional, (8) uji coba produk operasional (uji efektif produk), (9) revisi produk final (revisi produk yang efektif), dan (10) diseminasi dan implementasi produk hasil pengembangan (tujuannya agar produk yang baru saja dikembangkan dapat dipakai secara luas oleh pelaku olahraga, para pengajar di usia dini, dan masyarakat). Akan tetapi, dalam penelitian ini, metode penelitian dan pengembangan yang digunakan akan disederhanakan, atau hanya sampai tahap uji efektifitas produk.

Penelitian pengembangan ini akan dilaksanakan di beberapa tempat latihan atlet voli pantai di NTB, yaitu pada uji coba skala kecil melibatkan atlet voli pantai UKM (Unit Kegiatan Mahasiswa) Bola Voli Universitas Pendidikan Mandalika (UNDIKMA) Mataram, dan uji coba skala besar melibatkan atlet voli pantai di Kabupaten Lombok Tengah, sedangkan untuk uji efektifitas produk melibatkan atlet voli pantai di NTB.

Target/sasaran yang diharapkan dari penelitian pengembangan ini adalah sebuah produk berupa model latihan imagery untuk meningkat- kan ketepatan floating service yang dirancang berdasarkan permasalahan di dalam latihan floating service pada atlet voli pantai, produk yang dihasilkan ini diharapkan: (1) meningkatkan kemampuan ketepatan floating service (2) membantu pelatih dalam mengembangkan model latihan imagery dengan produk yang dihasilkan yakni berupa buku panduan model latihan imagery untuk meningkatkan ketepatan floating service.

Subjek dalam penelitian ini adalah atlet voli pantai di NTB, kemudian sesuai dengan tahapan penelitian, akan dilaksanakan beberapa tahapan proses pengambilan data. Dalam penelitian ini dilakukan uji coba model di lapangan, yaitu uji coba model skala kecil dan besar. Untuk uji coba produk skala kecil melibatkan atlet voli pantai UKM Bola Voli IKIP Mataram sebanyak 4 atlet dan uji coba model skala besar melibatkan atlet voli pantai Kabupaten Lombok Tengah sebanyak enam orang, sedangkan untuk uji efektifitas produk melibatkan atlet voli pantai di NTB yang berjumlah delapan orang.

Penelitian dan pengembangan ini menggunakan instrumen yang disusun oleh peneliti berupa panduan analisis kebutuhan yang dikemas dalam wawancara, kuesioner observasi Sistematik pada uji skala kecil dan skala besar, dan lembar penilaian atlet. Kemudian ketiga instrumen penilaian akan dinilai oleh para ahli dan pelatih voli pantai. Ujicoba lapangan baik uji skala kecil maupun skala besar, pedoman yang digunakan untuk mengungkap pendapat dari para expert judgement adalah pedoman yang sama. Selanjutnya pada uji skala kecil dan skala besar diambil pula data kuesioner kepada atlet voli pantai yang menjadi subjek uji coba. Pengambilan pendapat dari atlet voli pantai dapat membantu perbaikan kualitas dari model latihan fundamental voli pantai khususnya pada floating service. Untuk tahap pasca pengembangan adalah uji efektifitas produk akhir yang sudah menjadi produk pengembangan final. Produk akhir diuji efektifitas dengan penerapan langsung di lapangan kepada atlet voli pantai di NTB.

Penggunaan instrumen dalam penelitian pengembangan ini sebelum digunakan untuk mengambil data, maka harus melalui validasi instrumen dengan tujuan hasil data yang diperoleh valid dan realiabel. Validator instrumen dalam penelitian ini melibatkan para ahli istrumen. Selanjutnya instrumen yang sudah valid itu dapat digunakan dalam membuat analisis kebutuhan, instrumen untuk membuat draf awal model, uji coba produk, dan instrumen keefektifan 
model. Instrumen yang digunakan dalam penelitian pengembanagn ini divalidasi sebelum digunakan untuk mengambil data di lapangan.

\section{Teknik Analisis Data}

Analisis Validitas dan Reliabilitas Instrumen

Analisis validitas dan reliabilitas instrumen menggunakan Formula Aikens'V yang digunakan untuk menghitung content validity coefficient yang didasarkan pada hasil penilaian dari pakar/ahli sebanyak n orang terhadap suatu item dari segi sejauh mana item tersebut mewakili konstruk yang diukur. Formula yang diajukan oleh Aiken seperti terpapar pada Rumus 1 (Azwar, 2015, p. 112). Dari Rumus 1 diketahui bahwa $\mathrm{s}=\mathrm{r}-\mathrm{lo}$, dari s diketahui bahwa lo merupakan penilaian validitas yang terendah (1), c adalah penilaian validitas tertinggi (4). Sedangkan $r$ adalah angka yang diberikan oleh penilai/ ahli (skor), dan n merupakan jumlah sampel.

$\mathrm{V}=\Sigma \mathrm{s} /[\mathrm{n}(\mathrm{c}-1)]$

Analisis Kelayakan (Validitas) Draft Awal Produk

Validasi draf awal produk menggunakan instrumen skala penilaian sebagai bahan panduan dalam menilai draft awal model latihan imagery untuk meningkatkan ketepatan floating service pada atlet voli pantai NTB. Berdasarkan penilaian dari para ahli materi terhadap skala nilai, terlihat bahwa total nilai draf awal model latihan imagery telah memenuhi persyaratan kelayakan untuk diujicobakan di lapangan.

Penelitian pengembangan ini berupa draf awal latihan imagery dianggap layak untuk diujicobakan sebelum pengujian skala kecil maupun skala besar, apabila para ahli materi telah memberikan validasi dan menyatakan minimal tingkat validitas yang dicapai dalam kategori sesuai. Gratton dan Jones (2014, p. 202) menjelaskan teknik penilaian draft awal produk menggunakan persentase kelayakan yang terangkum dalam Rumus 2. Dari Rumus 2 diketahui bahwa $\mathrm{P}$ adalah frekuensi relatif/angka persentase yang dicari persentasenya, $f$ adalah frekuensi (jumlah skor penilaian), $\mathrm{N}$ adalah jumlah seluruh data (butir soal)/skor maksimal, dan $100 \%$ merupakan konstanta.

\section{$P=f / N x(100 \%)$}

Setelah persentase kelayakan didapat, dan produk dikatakan layak bilamana persentase kelayakan lebih dari 75\% (>75\%) atau disebut layak. Dalam hal ini terdapat 4 kategori kelayakan sesuai persentase kelayakan, yaitu layak, cukup layak, kurang layak dan tidak layak.

Tabel 1. Klasifikasi kelayakan

\begin{tabular}{ll}
\hline \multicolumn{1}{c}{ Skor Nilai } & \multicolumn{1}{c}{ Keterangan } \\
\hline$>75 \%-100 \%$ & Layak \\
$>50 \%-75 \%$ & Cukup layak \\
$>25 \%-50 \%$ & Kurang layak \\
$<25 \%$ & Tidak layak \\
\hline
\end{tabular}

Analisis Observasi Model

Pada analisis model terdapat dua data dari dua instrumen yaitu data yang dihasilkan dari hasil observasi model yang diberikan oleh para ahli dan praktisi. Analisis yang dilakukan adalah dengan hasil penilaian terhadap item-item observasi dijumlahkan, lalu diambil rerata nilainya dikonversikan untuk mengetahui kategorinya. Berdasarkan skala yang dipakai dalam pengkorversian menggunakan skala empat maka yang dipakai dalam perhitungan normatif menggunakan empat kategori yaitu tidak sesuai, cukup sesuai, sesuai, dan sangat sesuai yang akan dipaparkan pada model latihan imagery.

\section{HASIL DAN PEMBAHASAN}

\section{Hasil Analisis Kebutuhan}

Analis kebutuhan atau studi pendahuluan merupakan tahap awal dalam melakukan penelitian dan pengembangan. Hasil dari analisis kebutuhan akan digunakan sebagai dasar dalam penyusunan draft awal model latihan imagery yang bertujuan untuk meningkatkan ketepatan floating service atlet voli pantai NTB. Data dari analisis kebutuhan didapatkan dari hasil observasi dan wawancara yang dilakukan peneliti kepada pelatih-pelatih voli pantai di NTB.

Berdasarkan hasil analisis kebutuhan di lapangan yang dilakukan dengan metode observasi dan wawancara kepada pelatih voli pantai maka didapatkan informasi sebagai berikut: (1) Program latihan dasar yang khusus untuk melakukan floating service masih belum maksimal dilakukan oleh para atlet karena metode latihan yang konstan dan alokasi waktu yang kurang efisien dalam penerapan latihan, (2) Program latihan yang disusun oleh pelatih masih didominasi pada aspek latihan fisik, teknik dan taktik daripada mengeksplorasi latihan fundamental dari floating service yang merupakan serangan utama dalam permainan bola voli, (3) Metode latihan imagery yang difokuskan untuk meningkatkan aspek psikologis atlet masih belum dite- 
rapkan oleh para pelatih, dan (4) Proses evaluasi yang dilakukan pelatih masih mendeskripsikan secara umum kemampuan para atlet tanpa menelaah latihan-latihan fundamental yang bisa meningkatkan motivasi atlet dalam melakukan latihan maupun pertandingan.

Informasi tersebut menunjukkan bahwa terdapat permasalahan dalam penyusunan program latihan yang dilakukan pelatih masih belum terlalu terfokus pada pengembangan aspek psikologis atlet, dan latihan imagery juga masih belum diterapkan dalam latihan. Oleh karena itu, dari hasil informasi yang dikumpulkan, peneliti akan menyusun sebuah draft awal model latihan imagery untuk meningkatkan ketepatan floating service atlet voli pantai di NTB.

\section{Deskripsi Draft Awal Produk}

Pembuatan draft awal produk harus disesuaikan dengan kajian teoritis tentang metode latihan dan hasil analisis kebutuhan di lapangan, dalam penelitian ini produk yang akan dikembangkan berupa model latihan imagery terhadap ketepatan floating service, maka langkah selanjutnya adalah mendeskripsikan draft awal produk model latihan imagery, sebagai berikut:

\section{Pengertian Imagery}

Istilah imagery, visualisasi, dan latihan mental telah digunakan secara beragantian oleh para peneliti, psikolog olahraga, pelatih dan atlet untuk menggambarkan teknik pelatihan mental yang kuat. Pada awal perkembangan latihan mental merupakan istilah yang dipakai untuk menggambarkan teknik latihan imagery, tetapi istilah ini hanya merujuk pada gambaran umum dari strategi berlatih dengan modalitas sensorik atau kognitif yang digunakan (Morris et al., 2005, p. 13). Selanjutnya, Wakefield et al. (2013, p. 115) menyatakan bahwa dewasa ini sebagian besar praktisi olahraga telah menggunakan latihan mental imagery yang menggambarkan teknik latihan mental terstruktur untuk menciptakan suatu kinerja olahraga yang optimal. Menurut Cumming (2008, p. 192) menjelaskan bahwa biasanya beberapa atlet menggunakan latihan imagery tidak terstruktur yang dilakukan spontan guna mencapai tujuan tertentu, mereka mengalami kesulitan untuk mendapatkan rincian atas isi verbalitas sebagai inti dari latihan imagery. Namun gambaran mental tidak hanya perilaku spontan dari individu untuk membayangkan sesuatu penampilan. Selanjutnya, Munzert et al. 2008, p. 440) menjelaskan bahwa gerakan imagery adalah proses melalui sebuah observasi ge- rakan di bawah intruksi pikiran, yang kemudian salah satunya dapat menampilkan gerakan imagery dari pandangan orang pertama.

Berdasarkan penjelasan tentang imagery berdasarkan kajian empiris, menunjukkan bahwa latihan imagery merupakan sebuah bentuk latihan mental (psikologis) yang mampu memberikan kontribusi positif dalam meningkatkan fokus dan kepercayaan diri atlet, serta membantu meningkatkan kinerja dalam olahraga.

\section{Bentuk Latihan Imagery}

Cox (2011, p. 281) menjelaskan bahwa mengembangkan kemampuan imagery pada model program latihan ini untuk mengembangkan dan memperluas isi dari fokus imagery secara umum pada tingkatan kemampuan mengendalikan diri dan menggambarkan sebuah peristiwa yang melibatkan pancaindra dari melihat sebuah gambaran. Sedangkan, Karageorghis dan Terry (2010, p. 173) bahwa imagery memiliki dua fungsi sentral yaitu pada ranah kognitif dan motivasi atau fungsi energi, fungsi kognitif memerlukan penggunaaan imagery untuk kemampuan pengalaman dalam skill olahraga dan strategi pada kompetisi tingkat atas atau professional, sedangkan fungsi motivasi termasuk dalam penggunaan imagery untuk mencapai tujuan akhir begitu juga untuk mengatasi secara efektif terhadap tuntutan pada olahraga dan untuk mengatur level arousal.

Hasil penelitian dari Komarudin (2017, p. 88) menjelaskan lima bentuk latihan imagery, yaitu: (1) Cognitive specific (CS): latihan imagery ini khusus untuk keterampilan olahraga yang spesifik, seperti melakukan servis dalam permainan bola voli, (2) Cognitive general (CG): latihan imagery ini merupakan strategi yang dilakukan secara rutin, (3) Motivational specific (MS): latihan imagery ini dilakukan untuk menentukan tujuan secara spesifik dan membentuk perilaku yang berorientasi pada tujuan, (4) Motivational general arousal: latihan imagery ini berhubungan dengan emosi dan performa, seperti merasa gembira dan semangat ketika bertanding di depan penonton yang banyak, dan (5) Motivational general mastery (MGM): latihan imagery ini terkait dengan penguasaan situasi olahraga.

Penjelasan bentuk-bentuk latihan imagery tersebut sangat relevan dengan kebutuhan dan tujuan yang diharapkan pada penyusunan model latihan imagery dalam penelitian ini. Oleh karena itu, dalam draft awal model latihan imagery, peneliti akan mengadopsi bentuk-bentuk latihan yang telah dijelaskan, sehingga diharapkan mampu memberikan dampak yang positif dan mem- 
berikan fasilitas terbaik kepada atlet untuk meningkatkan performa, kepercayaan diri, kognitif, motivasi, mengendalikan perhatian, dan melihat kemanapun secara visual selama pertandingan, selain itu latihan imagery dalam bentuk spesifik sangat efektif mengubah kecemasaan yang di alami oleh atlet.

Model

Secara umum model dapat diartikan sebagai pola atau bentuk yang di dalamnya terdapat langkah-langkah yang berguna sebagai alat untuk mempelajari serta memahami topik tertentu yang sesuai dengan tujuan yang akan dicapai. Menurut Sagala (2010, p. 175) model adalah sebagai kerangka konseptual yang digunakan sebagai pedoman dalam melakukan kegiatan. Model dapat dipahami sebagai: (1) suatu tipe atau desain, (2) suatu deskripsi atau analogi, (3) suatu sistem asumsi-asumsi, data-data yang dipakai untuk menggambarkan secara sistematis suatu objek atau peristiwa, (4) suatu desain yang disederhanakan dari suatu sistem kerja, suatu terjemahan realitas yang disederhanakan, (5) suatu deskripsi dari suatu sistem yang mungkin atau imajiner, dan (6) penyajian diperkecil agar dapat menjelaskan dan menunjukkan sifat aslinya.

Ada berbagai macam bentuk dan tujuan dari penggunaan model yang disusun berdasarkan kebutuhan dan karakteristik pelaku/objek, dari pengertian model diatas dapat disimpulkan bahwa model diartikan sebagai kerangka konseptual yang digunakan sebagai pedoman dalam melakukan kegiatan yang disertakan oleh tahapantahapan pelaksanaan model yang telah disusun. Model juga diartikan seperangkat prosedur yang berurutan untuk mewujudkan suatu proses pemilihan ruang lingkup persoalan. Model juga memiliki bentuk atau konsep yang berbeda-beda berdasarkan dengan domain dan tujuan model itu sendiri.

Dalam penelitian ini, bentuk model akan disusun sesederhana mungkin agar mudah dipahami oleh pengguna yaitu pelatih maupun pembina olahraga voli pantai. Model di sini, menjelaskan dan menggambarkan setiap definisi konseptual dan langkah-langkah yang akan dilakukan dalam latihan imagery, seperti: definisi, tujuan, prosedur pelaksanaan, dan evaluasi latihan imagery.

Latihan

Latihan adalah merupakan aktivitas olahraga yang sistematik dalam waktu yang lama, ditingkatkan secara progresif dan individual yang mengarah pada ciri-ciri fungsi psikologis dan fisiologis manusia untuk mencapai sasaran yang ditentukan, dalam olahraga latihan mempunyai cakupan yang luas yaitu untuk memperbaiki kinerja fisik, teknik, taktik, maupun mental bermain (Sukadiyanto \& Muluk, 2011, p. 38). Begitu juga dengan Irianto (2018, p. 17) menjelaskan pengertian latihan adalah suatu proses mempersiapkan organisme atlet secara sistematis untuk mencapai mutu prestasi yang maksimal dengan diberi beban fisik dan mental yang teratur, terarah dan berulang-ulang. Sehingga dalam latihan terjadi proses penyempurnaan berolahraga melalui pendekatan ilmiah khususnya prinsip-prinsip pendidikan secara teratur dan terencana.

Berdasarkan pendapat teoritis tersebut dapat disimpulkan bahwa latihan adalah sebuah aktivitas olahraga yang mempunyai tujuan yang terprogram untuk menunjang sebuah prestasi. Begitu juga dengan hasil atau efek dari latihan itu sendiri yang berupa perubahan dari ciri fisik, motorik, dan psikis. Dari program latihan yang dibuat kebanyakan para pelatih selalu mempertimbangkan akan variasi latihan yang termasuk dalam prinsip dan asas latihan. Hasil dari latihan yang berupa peningkatan dalam fisik maupun taktik dirasa belum lengkap jika aspek psikis para atlet kurang diperhatikan, oleh karena itu latihan mental yang berkaitan dengan psikis atlet harus diperhatikan agar mendapatkan hasil yang maksimal dari program latihan itu sendiri. Cakupan latihan mental mempunyai beberapa macam jenis, salah satunya adalah latihan imagery.

Latihan imagery dalam penelitian ini akan disusun berdasarkan teori latihan yang disesuaikan dengan metode pelatih di lapangan. Latihan imagery akan dilakukan setelah program latihan inti yang diberikan pelatih telah selesai dilakukan, hal ini dilakukan agar tidak mengganggu program latihan yang telah disusun oleh pelatih, dan untuk memberikan kenyamanan kepada atlet untuk ikut berpartisipasi dalam latihan dengan sungguh-sungguh.

\section{Model Latihan Imagery}

Pelaksanaan latihan imagery yang dilakukan oleh atlet adalah dengan cara duduk sejenak dan diikuti dengan menutup mata, usahakan relaks terlebih dahulu, lalu bernapaslah dalamdalam beberapa kali usahakan membayangkan atau membuat imajinasi satu per satu pengalaman yang berhubungan dengan pancaindra lalu atlet dilatih untuk membuat khayalan-khayalan mental mengenai suatu gerakan atau keterampilan ter- 
tentu dengan membuat cognitive imagery. Dengan cara menyuruh atlet untuk melihat dan mengamati, memperhatikan, dan membanyangkan dengan seksama pola gerak tertentu.

Penjelasan tersebut didukung oleh Setyawati (2014, p. 52) yang menjelaskan di dalam penelitiannya bahwa imagery sering disebut dengan guided imagery, visualization, latihan mental, atau self-hypnosis. Imagery adalah teknik yang biasa digunakan oleh psikolog olahraga untuk membantu seseorang memvisualisasikan atau melatih mental berkaitan dengan kegiatan yang akan dilakukan, dalam konteks olahraga imagery digunakan untuk membantu atlet membuat visualisasi yang lebih nyata berkaitan dengan pertandingan atau kompetisi yang akan dijalaninya.

\section{Data Masukan dari Ahli dan Praktisi}

Setelah penyusunan draft awal produk/ model latihan imagery, maka langkah selanjutnya dalah melakukan validasi kepada pakar/ahli. Dalam penelitian ini, peneliti menggunakan tiga ahli, yaitu: (a) ahli/akademisi psikologi olahraga, (b) ahli/akademisi bola voli, dan (c) ahli/ praktisi dari pelatih voli pantai. Berdasarkan dari proses validasi ahli terhadap draft awal produk, maka peneliti memperoleh masukan-masukan guna perbaikan draf awal model latihan imagery untuk meningkatkan ketepatan floating service. Adapun masukan-masukan tersebut dari ahli dapat dilihat pada Tabel 2.

\section{Revisi Draft Awal Produk}

Draf awal produk yang sudah dibuat selanjutnya direvisi oleh peneliti sesuai dengan masukan dari para ahli, hal ini dilakukan untuk penyempurnaan model latihan imagery. Draf awal produk yang sudah mendapat validasi dari ahli materi, maka model boleh di ujicobakan di lapangan. Akan tetapi, jika belum mendapat validasi dari ahli maka draf awal produk terlebih dahulu direvisi sesuai dengan arahan dan masukan dari ahli. Hasil dari revisi draf awal produk selanjutnya diajukan untuk mendapatkan validasi draf model latihan imagery. Dalam mengajukan validasi draf awal produk kepada ahli, peneliti harus menyiapkan instrumen skala penilaian sebagai bahan panduan dalam menilai draft awal model latihan imagery untuk meningkatkan ketepatan floating service pada atlet voli pantai NTB.

\section{Validasi Isi Instrumen}

Sebelum instrumen digunakan dalam pengambilan data di lapangan, maka keseluruhan instrumen harus divalidasi untuk mengetahui validitas isi alat ukur yang akan digunakan dalam penelitian. Validasi keseluruhan instrumen menggunakan formula Aiken's V untuk menghitung content validity coefficient yang didasarkan pada hasil penilaian dari panel ahli sebanyak $\mathbf{n}$ orang terhadap suatu item dari segi sejauh mana item tersebut mewakili konstrak yang diukur. Tabel 3 merupakan penjelasan hasil validasi isi keseluruhan instrument.

Berdasarkan hasil analisis yang dipaparkan, maka dapat disimpulkan bahwa instrumen yang digunakan dalam pengambilan data seperti data observasi draf awal model, observasi skala kecil, observasi skala besar, dan efektifitas produk dilakukan menggunakan istrumen yang sudah dikatakan valid dari butir isinya.

Tabel 2. Masukan dari para Ahli terhadap Draf Awal Model Latihan Imagery

\begin{tabular}{|c|c|}
\hline Ahli & Masukan para ahli \\
\hline Pakar 1: & 1. Latihan imagery harus dilakukan di tempat yang nyaman, tenang, dan tidak terganggu \\
\hline Ahli Psikologi & oleh suara kendaraan atau suara-suara yang mengakibatkan kehilangan konsentrasi. \\
\hline \multirow[t]{3}{*}{ Olahraga } & $\begin{array}{l}\text { 2. Penjelasan dalam kalimat yang ada di dalam text imagery lebih ditekankan pada inti } \\
\text { latihan agar mudah dipahami atlet. }\end{array}$ \\
\hline & 3. Dalam melakukan gerakan floating service harus dilakukan secara baik dan benar. \\
\hline & 4. Alokasi waktu dalam latihan imagery harus efisien. \\
\hline Pakar 2: & 1. Penjelasan dalam tahapan floating service harus benar-benar dapat dipahami oleh atlet. \\
\hline \multirow{2}{*}{ Ahli Bola Voli } & 2. Para atlet harus diperhatikan ketika melaksanakan floating service. \\
\hline & $\begin{array}{l}\text { 3. Atlet harus benar-benar merasa rileks pada saat melakukan latihan imagery, jangan } \\
\text { sampai ada gangguan dari manapun. }\end{array}$ \\
\hline $\begin{array}{l}\text { Praktisi pelatih } \\
\text { voli pantai }\end{array}$ & $\begin{array}{l}\text { 1. Dalam latihan floating service atlet harus memahami setiap tahapan yang telah dijelaskan } \\
\text { oleh pelatih/peneliti, baik tahapan dalam melakukan gerakan floating service maupun } \\
\text { dalam mendapatkan hasil ketepatan yang diinginkan. }\end{array}$ \\
\hline
\end{tabular}


Jurnal Keolahragaan 7 (2), 2019 - 169

Johan Irmansyah, Muhammad Ridwan Lubis, Andi Gilang Permadi, Nune Wire Panji Sakti

Tabel 3. Hasil Validitas Isi Instrument menggunakan Formula Aiken's V

\begin{tabular}{|c|c|c|c|c|c|c|c|c|c|c|c|c|c|c|c|c|c|c|c|c|c|c|c|c|c|c|c|c|}
\hline \multirow{2}{*}{ 定 } & \multicolumn{2}{|c|}{$\begin{array}{c}\text { Item } \\
1\end{array}$} & \multicolumn{2}{|c|}{$\begin{array}{c}\text { Item } \\
2 \\
\end{array}$} & \multicolumn{2}{|c|}{$\begin{array}{c}\text { Item } \\
3 \\
\end{array}$} & \multicolumn{2}{|c|}{$\begin{array}{c}\text { Item } \\
4 \\
\end{array}$} & \multicolumn{2}{|c|}{$\begin{array}{c}\text { Item } \\
5 \\
\end{array}$} & \multicolumn{2}{|c|}{$\begin{array}{c}\text { Item } \\
6 \\
\end{array}$} & \multicolumn{2}{|c|}{$\begin{array}{c}\text { Item } \\
7 \\
\end{array}$} & \multicolumn{2}{|c|}{$\begin{array}{c}\text { Item } \\
8 \\
\end{array}$} & \multicolumn{2}{|c|}{$\begin{array}{c}\text { Item } \\
9 \\
\end{array}$} & \multicolumn{2}{|c|}{$\begin{array}{c}\text { Item } \\
10 \\
\end{array}$} & \multicolumn{2}{|c|}{$\begin{array}{c}\text { Item } \\
11 \\
\end{array}$} & \multicolumn{2}{|c|}{$\begin{array}{c}\text { Item } \\
12 \\
\end{array}$} & \multicolumn{2}{|c|}{$\begin{array}{c}\text { Item } \\
13 \\
\end{array}$} & \multicolumn{2}{|c|}{$\begin{array}{c}\text { Item } \\
14 \\
\end{array}$} \\
\hline & $\frac{\overline{0}}{\sqrt{n}}$ & is & $\frac{\dot{0}}{\frac{\pi}{n}}$ & is & $\frac{\overrightarrow{0}}{n}$ & $\infty$ & $\frac{\overline{0}}{n}$ & is & $\frac{\ddot{0}}{\omega}$ & is & $\frac{\dot{0}}{\tilde{w}}$ & $\infty$ & $\frac{\dot{0}}{n}$ & is & $\frac{\bar{s}}{n}$ & $\infty$ & $\frac{\overline{0}}{n}$ & is & $\frac{\bar{g}}{v}$ & n & $\begin{array}{l}\dot{\bar{\theta}} \\
\frac{\vec{w}}{\omega}\end{array}$ & is & $\frac{\dot{\sigma}}{w}$ & $\infty$ & $\frac{\bar{\sigma}}{n}$ & & $\frac{\ddot{0}}{\frac{0}{n}}$ & \\
\hline 1 & 4 & 3 & 3 & 2 & 4 & 3 & 4 & 3 & 4 & 3 & 3 & 7 & 3 & 2 & 4 & 3 & 3 & 2 & $\overline{4}$ & 3 & 4 & 3 & 3 & 2 & 4 & & 4 & \\
\hline 2 & 3 & 2 & 4 & 3 & 4 & 3 & 4 & 3 & 4 & 3 & 4 & & 4 & 3 & & 3 & & 2 & & 3 & 3 & 2 & $t$ & 3 & 4 & & & \\
\hline 3 & 4 & 3 & 4 & 3 & 4 & 3 & 3 & 2 & 3 & 2 & 3 & 2 & 4 & 3 & & 3 & & 3 & 3 & 2 & & 3 & 3 & 2 & & & & \\
\hline$\sum \mathrm{s}$ & 8 & & 8 & & 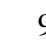 & & & & 8 & & 7 & & 0 & & & & & & & & & & & & . & & 9 & \\
\hline V & 0.8 & & 0.8 & & 1 & & & & & & & & 0.8 & & & & 0. & & & 89 & 0.8 & & 0. & & 1 & & 1 & \\
\hline Ket & Val & & $\mathrm{Va}$ & & & & & & & & & & $\mathrm{Va}$ & lid & & & & & & lid & $\mathrm{Va}$ & & $\mathrm{Va}$ & & $\mathrm{Val}$ & & Valic & \\
\hline
\end{tabular}

Validitas Draf Awal Produk

Draf awal produk/model latihan imagery yang dianggap layak untuk diujicobakan dalam skala kecil maupun skala besar adalah apabila para ahli/pakar telah memberikan validasi dan menyatakan minimal tingkat validitas yang dicapai dalam kategori sesuai. Berikut hasil validasi dari para ahli materi dan praktisi (Tabel 4).

Tabel 4. Data Rekapitulasi Draft Awal Produk dari Para Ahli

\begin{tabular}{cccc}
\hline Ahli & Skor & Nilai max & Persentase kelayakan \\
\hline Ahli 1 & 61 & 72 & 84 \\
Ahli 2 & 65 & 72 & 91 \\
Ahli 3 & 56 & 72 & 77 \\
\hline
\end{tabular}

Pada ahli pertama dihasilkan total skor 61 dan nilai maksimal 72 dari 18 item. Sedangkan persentase kelayakan sebesar $84 \%$ dengan menggunakan batas minimal dikatakan layak adalah $>75 \%$. Maka penilaian ahli pertama terhadap model latihan imagery dikatakan 'layak' karena $84 \%>75 \%$. Pada ahli kedua dihasilkan total skor 65 dan nilai maksimal 72 dari 18 item. Sedangkan persentase kelayakan sebesar $91 \%$ dengan menggunakan batas minimal dikatakan layak adalah $>75 \%$. Maka penilaian ahli kedua terhadap model latihan imagery dikatakan 'layak' karena 91\% > $75 \%$. Pada ahli ketiga dihasilkan total skor 56 dan nilai maksimal 72 dari 18 item. Sedangkan persentase kelayakan sebesar $77 \%$ dengan menggunakan batas minimal dikatakan layak adalah $>75 \%$. Maka penilaian ahli ketiga terhadap model latihan imagery dikatakan 'layak' karena $77 \%>75 \%$.

Berdasarkan hasil validitas draft awal produk/model latihan imagery menunjukkan bahwa dari ketiga ahli/pakar memberikan penilaian di atas standar yang telah ditentukan, ini berarti draft awal produk sudah valid dan bisa diujicobakan langsung pada tahap selanjutnya.

\section{Hasil Uji Coba Produk}

\section{Uji Coba Skala Kecil}

Setelah mendapatkan validasi para ahli/ pakar terhadap draf awal produk/model latihan imagery untuk meningkatkan ketepatan floating service pada atlet voli pantai di NTB dan sudah mendapatkan persetujuan kelayakan untuk diujicobakan, maka draf awal produk/model latihan imagery dapat di uji cobakan pada skala kecil. Adapun skala kecil dilaksanakan di UKM bola voli IKIP Mataram, dari hasil pelaksanaaan uji coba skala kecil, didapatkan data dari ahli materi (ahli psikologi olahraga dan ahli voli pantai) serta dari praktisi di lapangan. Data yang diperoleh, yaitu berupa: (1) data hasil observasi model latihan imagery, dan (2) data masukan terhadap model latihan imagery. Selain data tersebut juga didapatkan data respon dari atlet voli pantai di NTB.

Hasil dari uji skala kecil yang didapatkan pada ahli pertama dihasilkan total skor 30 dan nilai maksimal 36 dari 9 item. Sedangkan persentase kelayakan sebesar $83.3 \%$ dengan menggunakan batas minimal dikatakan layak adalah $>75 \%$. Maka penilaian ahli pertama terhadap model latihan imagery dikatakan 'layak' karena 83.3\% $>75 \%$. Pada ahli kedua dihasilkan total skor 29 dan nilai maksimal 36 dari 9 item. Sedangkan persentase kelayakan sebesar $80.5 \%$ dengan menggunakan batas minimal dikatakan layak adalah $>75 \%$. Maka penilaian ahli kedua terhadap model latihan imagery dikatakan 'layak' karena $80.5 \%>75 \%$. Pada ahli ketiga dihasilkan total skor 32 dan nilai maksimal 36 dari 9 item. Sedangkan persentase kelayakan sebesar $88.8 \%$ dengan menggunakan batas minimal dikatakan layak adalah $>75 \%$. Maka penilaian ahli ketiga terhadap model latihan imagery dikatakan 'layak' karena $88.8 \%>75 \%$.

Berdasarkan hasil ujicoba skala kecil menggunakan model latihan imagery, menunjukkan hasil bahwa dari ketiga ahli/pakar memberikan penilaian di atas standar yang telah ditentukan, ini berarti model latihan imagery 
Jurnal Keolahragaan 7 (2), 2019 - 170

Johan Irmansyah, Muhammad Ridwan Lubis, Andi Gilang Permadi, Nune Wire Panji Sakti

sudah bisa diujicobakan pada tahap ujicoba skala besar.

\section{Uji Coba Skala Besar}

Setelah mendapatkan validasi para ahli materi terhadap draf awal produk model latihan imagery untuk meningkatkan ketepatan floating service pada atlet voli pantai di NTB dan sudah mendapatkan persetujuan kelayakan untuk diujicobakan, serta telah mendapatkan kelayakan pada ujicoba skala kecil, model latihan imagery dapat di ujicobakan pada skala besar. Adapun skala besar dalam penelitian ini dilaksanakan di klub bola voli Lombok Tengah, dari hasil pelaksanaaan uji coba skala besar, didapatkan data dari ahli (ahli psikologi olahraga dan ahli voli pantai) serta dari praktisi di lapangan dalam hal ini adalah pelatih voli pantai. Data yang diperoleh, yaitu berupa: (1) data hasil observasi model latihan imagery, dan (2) data masukan terhadap model latihan imagery. Selain data tersebut juga didapatkan data respon dari atlet voli pantai di NTB.

Hasil dari uji skala besar yang didapatkan pada ahli pertama dihasilkan total skor 34 dan nilai maksimal 36 dari 9 item. Sedangkan persentase kelayakan sebesar $94.4 \%$ dengan menggunakan batas minimal dikatakan layak adalah $>75 \%$. Maka penilaian ahli pertama terhadap model latihan imagery dikatakan 'layak' karena 94.4\% $>75 \%$. Pada ahli kedua dihasilkan total skor 33 dan nilai maksimal 36 dari 9 item. Sedangkan persentase kelayakan sebesar $91.6 \%$ dengan menggunakan batas minimal dikatakan layak adalah $>75 \%$. Maka penilaian ahli kedua terhadap model latihan imagery dikatakan 'layak' karena $91.6 \%>75 \%$. Pada ahli ketiga dihasilkan total skor 34 dan nilai maksimal 36 dari 9 item. Sedangkan persentase kelayakan sebesar $94.4 \%$ dengan menggunakan batas minimal dikatakan layak adalah $>75 \%$. Maka penilaian ahli ketiga terhadap model latihan imagery dikatakan 'layak' karena $94.4 \%>75 \%$.

Berdasarkan hasil ujicoba skala besar menggunakan model latihan imagery, menunjukkan hasil bahwa dari ketiga ahli/pakar memberikan penilaian di atas standar yang telah ditentukan, ini berarti model latihan imagery sudah dinyatakan layak dalam melakukan uji efektivitas untuk meningkatkan ketepatan floating service atlet voli pantai di NTB. Akan tetapi, sebelum melakukan uji efektivitas, terlebih dulu peneliti harus melakukan revisi produk yang telah dihasilkan, ini dilakukan untuk meminimalisasi kekurangan-kekurangan yang terdapat dalam produk dan untuk meningkatkan validitas, reliabilitas, dan kredibilitas produk.

\section{Revisi Produk}

Revisi produk bertujuan untuk melakukan perbaikan model latihan imagery untuk meningkatkan ketepatan floating service atlet voli pantai di NTB berdasarkan masukan dari ahli dan analisis data model latihan imagery. Adapun revisi yang dilakukan mengacu pada kesesuaian model dengan tujuan latihan, efektifitas waktu dalam pelaksanaan latihan imagery, respon atlet dalam memahami bentuk model latihan imagery, serta faktor kemudahan dan tingkat kesulitan dalam melakukan latihan imagery untuk mencari peningkatan di dalam ketepatan floating service pada atlet voli pantai di NTB yang terdiri dari uji coba lapangan skala kecil dan juga uji coba lapangan skala besar.

Berikut beberapa revisi yang dilakukan peneliti terhadap model latihan imagery: (1) Persiapan alat yang dibutuhkan dalam latihan imagery, seperti: lapangan bola voli, net, bola voli, peluit untuk menandakan dimulainya tes, dan cone, (2) Jumlah peserta yang dilibatkan dalam latihan imagery, yaitu sebagian atlet voli pantai di NTB yang memiliki kemampuan servis yang cukup baik, dan tidak ada pembeda antara peserta putra maupun putri dalam pelaksanan latihan imagery, (3) Durasi keseluruhan latihan imagery atau waktu yang digunakan dalam latihan imagery selama 30-45 menit, dan (4) Tata cara pelaksanaan keseluruhan latihan imagery, yaitu tingkat konsentrasi para atlet ketika melakukan latihan imagery dengan bimbingan atau panduan seorang pelatih yang mengarahkan fokus imajinasi dengan menggunakan text dan juga mengkondisikan tempat latihan yang sesuai dengan kriteria ideal untuk melaksanakan latihan imagery.

\section{Kajian Produk Akhir}

Kajian produk akhir yang disusun dalam penelitian dan pengembangan ini adalah berupa buku panduan model latihan imagery untuk meningkatkan ketepatan floating service yang terdiri dari tiga tahap kegiatan, yaitu pertama kegiatan floating service awal, kedua penerapan imagery dan ketiga adalah kegiatan floating service tahap akhir. Model latihan yang disusun disesuaikan dengan program latihan voli pantai di NTB. Model latihan juga mengacu pada ketentuan tahapan latihan imagery dan tahapan floating service. Model latihan imagery ini ditujukan kepada pelatih voli pantai di NTB. Produk akhir 


\section{Jurnal Keolahragaan 7 (2), 2019 - 171}

Johan Irmansyah, Muhammad Ridwan Lubis, Andi Gilang Permadi, Nune Wire Panji Sakti

dalam penelitian pengembangan ini berupa buku pedoman pelaksanaan model latihan imagery.

\section{Efektifitas Produk Akhir}

Produk akhir model latihan imagery untuk meningkatkan ketepatan floating service akan dilakukan dengan uji efektifitas menggunakan analisis statistik uji t paired. Sebelum melakukan uji analisis statistik dilakukan uji prasyarat analisis, yaitu uji normalitas dan uji homogenitas.

\section{Uji Normalitas}

Uji normalitas digunakan untuk mengetahui apakah suatu data mengikuti sebaran normal atau tidak, dan untuk mengetahui apakah data tersebut berdistribusi normal atau tidak. Analisis statistik yang digunakan dalam melakukan uji normalitas adalah dengan uji KolmogorofSmirnov. Data dinyatakan berdistribusi normal apabila nilai signifikansi lebih besar dari $>0.05$. Adapun data hasil uji normalitas dapat dilihat pada Tabel 5.

Berdasarkan Tabel 5, menunjukkan bahwa data pretest dan posttest latihan imagery terhadap ketepatan floating service berdistribusi normal dengan nilai signifikansi 0.898 dan 0.919 lebih besar dari $>0.05$.
Uji Homogenitas

Dalam penelitian ini, uji homogenitas varians tetap dilakukan untuk mengetahui kesamaan kondisi subjek sehingga jika terjadi perubahan selama perlakuan maka perubahan tersebut diakibatkan oleh perlakuan yang diberikan. Uji homogenitas ini menggunakan nonparametric test dengan Two Related Sample Test dengan kriteria jika nilai signifikasnsi $(\mathrm{P}>0,05)$ berarti homogen, sedangkan jika nilai signifikansi $(\mathrm{P}<0,05)$ berarti tidak homogen. Adapun data hasil uji homogenitas dapat dilihat pada Tabel 6.

Berdasarkan Tabel 6, menunjukkan bahwa data pretest dan posttest latihan imagery terhadap ketepatan floating service dikatakan homogen (sama) dengan nilai signifikansi 0.07 lebih besar dari $>0.05$.

Uji t

Setelah melakukan uji normalitas dan uji homogenitas, maka langkah selanjutnya adalah melakukan uji $\mathrm{t}$ untuk mengetahui apakah ada pengaruh dari model latihan imagery yang di terapkan terhadap ketepatan floating service. Uji $\mathrm{t}$ ini dianalisis menggunakan Paired Sample Test berdasarkan hasil pretest dan posttest. Hasil analisis uji t terlihat pada Tabel 7.

Tabel 5. Hasil Uji Normalitas Model Latihan Imagery

\begin{tabular}{lccc}
\hline \multicolumn{2}{c}{ One-Sample Kolmogorov-Smirnov Test } & Pretest & Posttest \\
\hline $\mathrm{N}$ & & 8 & 8 \\
Normal Parameters $^{\mathrm{a}}$ & Mean & 22.75 & 25.38 \\
& Std. Deviation & 4.234 & 3.503 \\
Most Extreme Differences & Absolute & 0.202 & 0.196 \\
& Positive & 0.108 & 0.150 \\
& Negative & -0.202 & -0.196 \\
Kolmogorov-Smirnov Z & & 0.573 & 0.554 \\
Asymp. Sig. (2-tailed) & & 0.898 & 0.919 \\
Test distribution is Normal & & \\
\hline
\end{tabular}

Tabel 6. Hasil Uji Homogenitas Model Latihan Imagery

\begin{tabular}{ll}
\hline Marginal Homogeneity Test & Pretest \& Posttest \\
\hline Distinct Values & 11 \\
Off-Diagonal Cases & 8 \\
Observed MH Statistic & 182.000 \\
Mean MH Statistic & 192.500 \\
Std. Deviation of MH Statistic & 3.905 \\
Std. MH Statistic & -2.689 \\
Asymp. Sig. (2-tailed) & 0.07 \\
\hline
\end{tabular}

Tabel 7. Hasil Uji t Model Latihan Imagery terhadap Ketepatan Floating Service

\begin{tabular}{llllll}
\hline Paired Samples Test & & & & & \\
\hline Paired Differences & Mean & Std. Deviation & t & df & Sig. (2-tailed) \\
Pretest-posttest & -2.625 & 0.916 & 8.104 & 7 & 0.000 \\
\hline
\end{tabular}


Berdasarkan hasil analisis uji t menggunakan Paired Sample Test pada Tabel 7, menunjukkan bahwa peningkatan pretest-posttest ketepatan floating service dengan nilai t sebesar 8.104 dan signifikansi $0.000<0.05$, maka dapat disimpulkan bahwa peningkatan floating service sebelum dan sesudah diberikan latihan imagery mendapatkan peningkatan yang signifikan atau ada pengaruh yang signifikan dari latihan imagery terhadap peningkatan ketepatan floating service.

\section{SIMPULAN}

Berdasarkan hasil penelitian dan pengembangan, maka dapat disimpulkan bahwa: Pertama, pengembangan model latihan imagery yang dilakukan menggunakan metode Research and Development telah menghasilkan sebuah produk yang layak untuk diterapkan di lapangan. Kelayakan produk dihasilkan dari penelitian dan pengembangan yang telah dilakukan peneliti sesuai dengan sistematika penelitian dan prosedur yang benar. Data awal peneliti dapatkan dari studi pendahuluan (analisis kebutuhan) yang menunjukkan kekurangan-kekurangan dalam latihan psikologis atlet. Dari data awal tersebut, peneliti mulai merancang draft awal produk sesuai dengan kebutuhan di lapangan, kemudian para ahli materi dan praktisi memberikan masukan terhadap draft awal produk. Selanjutnya, hasil analisis uji coba skala kecil dan skala besar pada model latihan imagery terhadap ketepatan floating service, didapatkan hasil penilaian dari para ahli bahwa produk yang dihasilkan dikatan 'layak' untuk diterapkan di lapangan.

Kedua, Hasil analisis uji t menggunakan Paired Sample Test, menunjukkan bahwa peningkatan pretest-posttest ketepatan floating service dengan nilai t sebesar 8.104 dan signifikansi $0.000<0.05$, maka dapat disimpulkan bahwa peningkatan floating service sebelum dan sesudah diberikan latihan imagery mendapatkan peningkatan yang signifikan atau ada pengaruh yang signifikan dari latihan imagery terhadap peningkatan ketepatan floating service.

Dengan adanya produk yang dihasilkan dalam penelitian dan pengembangan ini, berupa pedoman model latihan imagery untuk peningkatan ketepatan floating service atlet voli pantai, diharapkan mampu memberikan kontribusi dalam memberikan variasi latihan yang terfokus pada aspek psikologis (mental) atlet. Penelitian yang akan datang diharapkan lebih menekankan untuk mengeksplorasi dan mengkaji model/ben- tuk latihan psikologis (mental) yang mendukung peningkatan performa atlet dan prestasi olahraga.

\section{DAFTAR PUSTAKA}

Azwar, S. (2015). Reliabilitas dan validitas. Pustaka Pelajar.

Cox, R. H. (2011). Sport Psychology Concepts and Applications. Mc Graw Hill. https://doi.org/10.4324/9781315885094

Cumming, J. (2008). Investigating the relationship between exercise imagery, leisure-time exercise behavior, and selfefficacy. Journal of Applied Sport Psychology, 20(2), 184-198. https://doi.org/10.1080/104132007018105 70

Fani, R. A., \& Sukoco, P. (2019). Volleyball learning media using method of teaching games for understanding adobe flashbased. Psychology, Evaluation, and Technology in Educational Research, 2(1), 34. https://doi.org/10.33292/petier.v2i1.6

Filgueiras, A. (2017). Imagery for the improvement of serving in beach volleyball: A single case study. Revista Brasileira de Psicologia Do Esporte, 6(3). https://doi.org/10.31501/rbpe.v6i3.7337

Firmansyah, H. (2011). Perbedaan pengaruh latihan imagery dan tanpa latihan imagery terhadap keterampilan senam dan kepercayaan diri atlet. Jorpres (Jurnal Olahraga Prestasi), 7(7), 1-10. https://doi.org/10.21831/jorpres.v7i7.1027 1

Gall, M. D., Gall, J. P., Borg, W. R. D., \& Gall, J. P. (2003). Educational research: An introduction (7th ed.). Pearson Education Inc.

Gratton, C., \& Jones, I. (2014). Research methods for sports studies. Routledge.

Irianto, D. P. (2018). Dasar-dasar latihan olahraga untuk menjadi atlet juara. Pohon Cahaya.

Irmansyah, J. (2017). Evaluasi program pembinaan prestasi cabang olahraga bola voli pantai. Jurnal Keolahragaan, 5(1), 24. https://doi.org/10.21831/jk.v5i1.12759

Irmansyah, J., Lubis, M. R., \& Permadi, A. G. (2018). Model latihan imagery terhadap ketepatan floating service atlet voli pantai NTB. Jurnal Ilmiah Mandala Education, 4(2), 100. https://doi.org/10.36312/jime.v4i2.418 


\section{Jurnal Keolahragaan 7 (2), 2019 - 173}

Johan Irmansyah, Muhammad Ridwan Lubis, Andi Gilang Permadi, Nune Wire Panji Sakti

Jose, J., \& Joseph, M. M. (2018). Imagery: It's effects and benefits on sports performance and psychological variables: A review study. International Journal of Physiology, Nutrition and Physical Education, 3(2), 190-193. http://www.journalofsports.com/pdf/2018/ vol3issue2/PartE/3-2-41-617.pdf

Karageorghis, C., \& Terry, P. (2010). Inside sport psychology. Human Kinetics.

Komarudin, K. (2017). Psikologi olahraga. Remaja Rosdakarya.

MacKenzie, S., Kortegaard, K., LeVangie, M., \& Barro, B. (2012). Evaluation of two methods of the jump float serve in volleyball. Journal of Applied Biomechanics, 28(5), 579-586. https://doi.org/10.1123/jab.28.5.579

Mizuguchi, N., Nakata, H., Uchida, Y., \& Kanosue, K. (2012). Motor imagery and sport performance. The Journal of Physical Fitness and Sports Medicine, l(1),

103-111. https://doi.org/10.7600/jpfsm.1.103

Morris, T., Spittle, M., \& Watt, A. P. (2005). Imagery in sport. Human Kinetics.

Munzert, J., Zentgraf, K., Stark, R., \& Vaitl, D. (2008). Neural activation in cognitive motor processes: comparing motor imagery and observation of gymnastic movements. Experimental Brain Research, 188(3), 437-444. https://doi.org/10.1007/s00221-008-1376$\mathrm{y}$

Palao, J. M., Manzanares, P., \& Ortega, E. (2009). Techniques used and efficacy of volleyball skills in relation to gender. International Journal of Performance Analysis in Sport, 9(2), 281-293. https://doi.org/10.1080/24748668.2009.11

\section{4}

Priyanto, J., Hidayah, T., \& Nugroho, P. (2014). Model pembinaan prestasi olahraga voli pantai di Kabupaten Indramayu tahun 2013. Journal of Sport Sciences and Fitness, 3(1). https://journal.unnes.ac.id/sju/index.php/js sf/article/view/6205

Sagala, S. (2010). Konsep dan makna pembelajaran. Alfabeta.

Setyawati, H. (2014). Strategi intervensi peningkatan rasa percaya diri melalui imagery training pada atlet wushu Jawa Tengah. Journal of Physical Education Health and Sport, 1(1). https://doi.org/10.15294/jpehs.v1i1.3012

Sugiyono. (2010). Metode penelitian kuantitatif kualitatif dan $R \& D$. Alfabeta.

Sukadiyanto \& Muluk, D. (2011). Pengantar teori dan metodologi melatih fisik. Lubuk Agung.

Wakefield, C., Smith, D., Moran, A. P., \& Holmes, P. (2013). Functional equivalence or behavioural matching? A critical reflection on 15 years of research using the PETTLEP model of motor imagery. International Review of Sport and Exercise Psychology, 6(1), 105-121. https://doi.org/10.1080/1750984X.2012.7 24437

Wilson, F. R., Pan, W., \& Schumsky, D. A. (2012). Recalculation of the critical values for lawshe's content validity ratio. Measurement and Evaluation in Counseling and Development, 45(3), 197210.

https://doi.org/10.1177/074817561244028 6 